\title{
Determination of the inorganic composition and short term effect of aqueous extracts of root, pod, and stem of Telfairia occidentalis on some hematological parameters in rats
}

\author{
Enyinnaya A Ogbonnaya ${ }^{1}$, Patrick O Uadia ${ }^{2}$ \\ ${ }^{1}$ Lecturer, Department of Biochemistry, Faculty of Science, University of Port Harcourt, Port Harcourt, ${ }^{2}$ Professor, \\ Department of Biochemistry, Faculty of Life Sciences, University of Benin, Benin, Edo State, Nigeria
}

Aims and Objectives: This study is to investigate the inorganic composition and the effect of fourteen (14) -day oral administration of aqueous extracts of root, pod and stem of Telfairia occidentalis in rats.Materials and Methods: Plant samples were analyzed for $\mathrm{K}, \mathrm{P}$, $\mathrm{Mg}, \mathrm{Ca}, \mathrm{S}, \mathrm{Mn}, \mathrm{Fe}, \mathrm{Cu}, \mathrm{Zn}, \mathrm{Pb}$, and Crusing atomic absorption spectrophotometry (AAS). Wister rats of both sexes were assigned to sixteen (16) groups of 4 animals per group. Different animal groups received distilled water and root, stem, and pod extracts at the doses of $250,750,1500,2250$, and $3000 \mathrm{mg} / \mathrm{kg}$ of body weight. All animals were treated for 14 days and sacrificed on the $15^{\text {th }}$ day. Results: The inorganic composition result showed that potassium (K) was the highest in abundance in all the samples (root, pod, and stem), compared to the other mineral elements. The root contained high levels of potassium and manganese; the stem had magnesium, manganese and iron while the pod contained high amount of potassium, manganese and iron. Hematological assay results showed reduction in the values of white blood cell (WBC) count for higher doses of root extract and all doses (except for $1500 \mathrm{mg} / \mathrm{kg} \mathrm{bw}$ ) of pod extract. Platelet count (PLT) was significantly high for root extract at $750 \mathrm{mg} / \mathrm{kg}$ bw. The stem extract showed a consistent decrease in the red blood cell (RBC) count for all dose administered. Conclusion: Telfairia occidentalis root, pod, and stem may be good sources of inorganic elements. The extracts have varying effects on hematological parameters which may be dosage- and duration- dependent.

Key words: Telfairia occidentalis, Inorganic composition, Hematological parameters, RDA, Root, Pod, Stem
http://nepjol.info/index.php/AJMS DOI: 10.3126/ajms.v7i5.13615 E-ISSN: 2091-0576 P-ISSN: 2467-9100

\section{INTRODUCTION}

In a world of close to 600 million people below $\$ 1.25$ a day and increasing hunger and sickness, there is the need for alternative and cheaper sources of food and medicine. ${ }^{1,2}$ The focus on non-conventional sources for food and medicine will enable the utilization of, hitherto, waste materials, in the generation of products that are of both nutritional and medicinal importance. Plant materials are composed of mineral elements and chemicals which can be harnessed for animal and human nutrition, and as remedy for ailments. The mineral elements in plants comprise of nitrogen, phosphorus, potassium, sodium, magnesium, calcium, manganese, iron, copper, zinc, lead and chromium. These are required in macro- or micro- level for cell metabolism. Their deficiency in the body may result in one ailment or the other.

Telfairia occidentalis belongs to the family Curcubitaceae. It is a food crop grown in some West African countries including Nigeria and used as vegetable. In ethno-medicine, the leaves are useful in the treatment of convulsion, anemia, diabetes, artherosclerosis, cardiovascular disease, hypertension, malaria and impotence. ${ }^{3-9}$ The aqueous root, 
stem and pod extracts, on short term investigation has been reported to have dose dependent effects on the liver and the kidney. ${ }^{10}$

There have been many investigations into the leaves and seed part of the plant and very few on the root, stem and pod. There is also uncertainty about the toxicity or otherwise of the root extract which has contributed to absolutely no nutritional use for this part of the plant although it may contain considerable level of nutrients and phytomedicines. ${ }^{11}$

In this study we investigated the quantitative elemental composition of the root, stem and pod of Telfairia occidentalis and also the effect of their extracts on some hematological parameters in rats.

\section{MATERIALS AND METHODS}

\section{Plant materials}

Telfairia occidentalis root stem and pod were collected from a farmland in obigbo, Port Harcourt, Nigeria. Samples were identified at the Plant Science and Biotechnology Department of University of Port Harcourt, Port Harcourt, Nigeria. The samples were washed, cut into bits and dried under shade.

\section{Animals}

Sixty four (64) Wistar albino rats, weighing (75-175g) were obtained from the animal house of Physiology Department, University of Nigeria, Enugu Campus. The animals were kept in the animal house of Biochemistry Dept, University of Port Harcourt and acclimatized for two (2) weeks with unlimited access to water and normal rat chow.

\section{Extraction of plant}

Plant samples were given mild heat treatment before blending in mechanical grater mill. The plant samples were ground into fine powder, and part of the powdered samples kept for elemental composition determination. Each sample (200 g) was macerated in adequate aqueous solvent for 24 hours to obtain crude extracts. The extract solutions were filtered and filtrates concentrated and reduced to constant weight at $30^{\circ} \mathrm{C}$. The extracts were stored in the refrigerator until used.

\section{Inorganic composition analysis}

This was carried out using Buck Scientific 205 Atomic Absorption/Emission Spectrophotometer.

The elements such as $\mathrm{K}, \mathrm{Mg}, \mathrm{Ca}, \mathrm{Mn}, \mathrm{Fe}, \mathrm{Cu}, \mathrm{Zn}$, $\mathrm{Pb}$, and $\mathrm{Cr}$ were analysed using atomic absorption spectrophotometry (AAS). Phosphorus and sulphur were analysed as phosphate and sulphate using a modified method. ${ }^{12}$

Contribution to recommended dietary allowance (RDA) This was calculated according to NRC. ${ }^{13}$

$$
\text { RDA }(\%)=\frac{\text { Concentration of the elements }}{\text { RDA }} \times 100
$$

Where RDA is recommended dietary allowance. ${ }^{13}$

\section{Animal treatments}

Wistar albino rats of both sexes were assigned to 16 groups of 4 animals per group. Different groups received distilled water (2 groups), root-, stem-, and pod extracts at doses of $250,750,1500,2250$, and $3000 \mathrm{mg} / \mathrm{kg}$ of body weight. All animals were treated for 14 days and sacrificed on the $15^{\text {th }}$ day.

Animals were placed under mild chloroform anesthesia, and blood collected by jugular laceration. Blood was collected into sample bottles containing potassium salt of ethylene diamine tetra acetic acid (EDTA) for analysis.

\section{Hematological analysis}

Packed Cell volume (PCV) was determined using microhaematocrit reader; hemoglobin by LED modified method; red blood cell (RBC) count was determined by formal citrate, formaldehyde and counting chamber method; white blood cell (WBC) count, using Turks solution and improved Neubauer counting chamber; and platelet by method of $1 \%$ ammonium oxalate solution and counting chamber. ${ }^{14-16}$

\section{Statistical analysis}

The data were analysed statistically using Analysis of Variance (ANOVA). Post-hoc comparisons were made using the Bonferroni's test. $\mathrm{P}<0.05$ was considered statistically significant.

\section{RESULTS}

The elemental composition analysis showed that potassium $(\mathrm{K})$ is the most abundance in all the Telfairia occidentalis samples (root, pod, and stem), compared to other inorganic components. This was followed by magnesium and calcium. Also potassium is concentrated more in the root and fruit pod, than in the stem. The Telfairia occidentalis root has a relatively high abundance of sodium, calcium and zinc. The pod has the highest concentrations of potassium, iron, zinc and lead. The stem has relatively high iron content, while chromium was absent in all the samples (Table 1).

Table 2 shows the mineral elements' contribution of Telfairia occidentalis root, stem and pod to recommended 
dietary allowance (RDA). The root and the pod showed higher contribution of potassium compared with stem. The stem showed the highest percentage contribution of magnesium. While manganese was highly contributed by root, stem and pod, the stem and the pod contributed more iron than the root.

The hematological assay result (Table 3) shows that the root and pod extracts had no significant effect on packed cell volume (PCV), hemoglobin count $(\mathrm{Hb})$ and red blood cell count $(\mathrm{RBC})$ for all the groups that received the extracts. A significant increase in platelet (PLT) level was observed for root at $750 \mathrm{mg} / \mathrm{kg}$ bw. There were significant reduction in the white blood cell count (WBC) for root extract (2250- and $3000 \mathrm{mg} / \mathrm{kg} \mathrm{bw}$ ) and all the pod extract groups (except $1500 \mathrm{mg} / \mathrm{kg}$ bw group).

The stem extract caused no significant change in the PCV, $\mathrm{Hb}, \mathrm{WBC}$, and PLT irrespective of dose administered (Table 4). However, it showed a significant reduction in the $\mathrm{RBC}$ value for all the doses compared to control.

\section{DISCUSSION}

The mineral composition and contribution to dietary intake indicated that the root and pod are good sources of potassium and manganese, while the stem is rich in magnesium, manganese and iron. The pod may also be a good source of iron. Potassium is known to be the most abundant cation in plant cells and plays essential roles in maintaining the membrane potential and ion homeostasis, and in enzyme activation, signal transduction, and many other physiological processes. ${ }^{18}$

Potassium was reported to lower blood pressure and reduces salt sensitivity. ${ }^{19,20}$ Research also suggested its effect on the structure and mechanical function of the heart, which can lead to improvements in many cardiovascular risk factors. ${ }^{21}$ Similar to Telfairia occidentalis leaf extract which was reported to be rich in iron, potassium and magnesium among others, and used in the treatment of anemia, high blood pressure and cardiovascular disorders, ${ }^{8,22}$ Telfairia occidentalis root, stem and pod extract may possess similar antianemic and antihypertensive properties.

Magnesium and manganese are involved in enzyme activation leading to energy production and protein metabolism. ${ }^{23,24}$ Manganese also plays a cofactor role in some antioxidative enzymes and is usually taken up by liver and kidney. ${ }^{25-28}$ High dose of manganese cause oxidative injury and low dose have antioxidant effect. ${ }^{29,30}$ Manganese is of importance to avian metabolism as it is

\section{Table 1: Inorganic composition of Telfairia occidentalis samples}

\begin{tabular}{|c|c|c|c|}
\hline Elements & Root & Stem & Pod \\
\hline Phosphorus (mg/100 g) & $5.58 \pm 0.52$ & $1.11 \pm 0.01$ & $3.97 \pm 0.93$ \\
\hline Potassium (mg/100 g) & $1653.00 \pm 23.00$ & $880.00 \pm 20.00$ & $1995.50 \pm 25.50$ \\
\hline Sulphur $(\mathrm{mg} / 100 \mathrm{~g})$ & $15.00 \pm 1.00$ & $30.00 \pm 5.00$ & $24.00 \pm 3.00$ \\
\hline Sodium (mg/100 g) & $53.63 \pm 3.53$ & $4.11 \pm 0.11$ & $12.43 \pm 1.44$ \\
\hline Chlorine (mg/100 g) & $0.28 \pm 0.01$ & $0.07 \pm 0.01$ & $0.60 \pm 0.11$ \\
\hline Magnesium (mg/100 g) & $118.00 \pm 9.00$ & $486.50 \pm 16.50$ & $155.00 \pm 15.00$ \\
\hline Calcium (mg/100 g) & $293.50 \pm 6.50$ & $120.00 \pm 8.00$ & $46.80 \pm 4.00$ \\
\hline Iron (mg/100 g) & $<0.10$ & $7.84 \pm 0.35$ & $8.15 \pm 1.00$ \\
\hline Copper (mg/100 g) & $0.00 \pm 0.00$ & $0.06 \pm 0.00$ & $0.03 \pm 0.00$ \\
\hline Zinc (mg/100 g) & $0.82 \pm 0.11$ & $2.09 \pm 0.09$ & $1.016 \pm 0.02$ \\
\hline Lead (mg/100 g) & $0.34 \pm 0.04$ & $0.40 \pm 0.10$ & $0.47 \pm 0.02$ \\
\hline Chromium (mg/100 g) & $0.00 \pm 0.00$ & $0.00 \pm 0.00$ & $0.00 \pm 0.00$ \\
\hline
\end{tabular}

Table 2: Contributions of mineral elements of Telfairia occidentalis root, stem and pod to RDA

\begin{tabular}{|c|c|c|c|c|}
\hline Elements & $\begin{array}{l}\mathrm{RDA}^{*} \\
(\mathrm{Mg})\end{array}$ & $\begin{array}{c}\text { Root contribution } \\
\text { to RDA (\%) }\end{array}$ & $\begin{array}{c}\text { Stem contribution } \\
\text { to RDA }(\%)\end{array}$ & $\begin{array}{c}\text { Pod contribution } \\
\text { to RDA (\%) }\end{array}$ \\
\hline Phosphorus (mg/100 g) & 1200 & 0 & 0 & 0 \\
\hline Potassium (mg/100 g) & 2000 & 83 & 44 & 100 \\
\hline Sodium $(\mathrm{mg} / 100 \mathrm{~g})$ & 500 & 11 & 1 & 2 \\
\hline Magnesium (mg/100 g) & 350 & 34 & 139 & 44 \\
\hline Calcium $(\mathrm{mg} / 100 \mathrm{~g})$ & 1200 & 24 & 10 & 4 \\
\hline Manganese $(\mathrm{mg} / 100 \mathrm{~g})$ & $2-5$ & $82-206$ & $135-338$ & $69-174$ \\
\hline Copper (mg/100 g) & $1.5-3$ & 0 & $2-4$ & $1-2$ \\
\hline Zinc $(\mathrm{mg} / 100 \mathrm{~g})$ & $12-19$ & $4-7$ & $11-17$ & $5-8$ \\
\hline
\end{tabular}




\begin{tabular}{|c|c|c|c|c|c|c|}
\hline \multirow[t]{2}{*}{ Group } & \multirow[t]{2}{*}{ Treatment } & \multicolumn{5}{|c|}{ Mean \pm SEM } \\
\hline & & Pcv (\%) & $\mathrm{Hb}(\mathrm{g} / \mathrm{dl})$ & $\operatorname{RBC}\left(\times 10^{9}\right)$ & WBC $\left(\times 10^{9}\right)$ & $\operatorname{PLT}\left(\times 10^{9}\right)$ \\
\hline 1 & Distilled water & $30.7 \pm 1.8$ & $10.4 \pm 0.6$ & $3.8 \pm 0.2$ & $6.9 \pm 0.7$ & $343.7 \pm 48.2$ \\
\hline 2 & Root extract $(250 \mathrm{mg} / \mathrm{kg} \mathrm{bw})$ & $35.3 \pm 0.9$ & $11.9 \pm 0.4$ & $4.3 \pm 0.1$ & $5.7 \pm 0.3$ & $317.3 \pm 40.2$ \\
\hline 3 & Root extract $(750 \mathrm{mg} / \mathrm{kg}$ bw & $39.0 \pm 2.0$ & $12.4 \pm 0.0$ & $4.5 \pm 0.00$ & $5.0 \pm 0.2$ & $652.0 \pm 18.0^{a}$ \\
\hline 4 & Root extract (1500 mg/kg bw) & $33.0 \pm 3.0$ & $11.5 \pm 1.5$ & $3.7 \pm 0.2$ & $6.7 \pm 0.4$ & $291.5 \pm 8.5$ \\
\hline 5 & Root extract (2250 mg/kg bw) & $29.5 \pm 1.5$ & $12.0 \pm 2.0$ & $3.6 \pm 0.1$ & $1.8 \pm 0.4^{\mathrm{a}}$ & $389.0 \pm 16.0$ \\
\hline 6 & Root extract (3000 mg/kg bw) & $32.0 \pm 3.0$ & $12.5 \pm 2.5$ & $3.1 \pm 0.3$ & $3.1 \pm 0.3^{a}$ & $292.0 \pm 9.0$ \\
\hline 7 & Pod extract $(250 \mathrm{mg} / \mathrm{kg} \mathrm{bw})$ & $33.0 \pm 2.0$ & $11.0 \pm 1.1$ & $3.6 \pm 0.2$ & $1.7 \pm 0.2^{\mathrm{a}}$ & $409.0 \pm 11.0$ \\
\hline 8 & Pod extract (1500 mg/kg bw) & $33.0 \pm 1.0$ & $11.3 \pm 0.3$ & $3.8 \pm 0.1$ & $5.8 \pm 0.6$ & $307.0 \pm 53.0$ \\
\hline 9 & Pod extract (2250 mg/kg bw) & $31.5 \pm 2.5$ & $11.5 \pm 0.5$ & $4.1 \pm 0.3$ & $3.0 \pm 1.6^{a}$ & $353.0 \pm 52.0$ \\
\hline 10 & Pod extract $(3000 \mathrm{mg} / \mathrm{kg} \mathrm{bw})$ & $30.0 \pm 0.0$ & $10.6 \pm 0.5$ & $3.6 \pm 0.1$ & $2.2 \pm 0.4^{\mathrm{a}}$ & $323.0 \pm 19.0$ \\
\hline
\end{tabular}

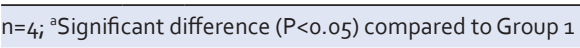

\begin{tabular}{|c|c|c|c|c|c|c|}
\hline \multirow[t]{2}{*}{ Group } & \multirow[t]{2}{*}{ Treatment } & \multicolumn{5}{|c|}{ Mean \pm SEM } \\
\hline & & Pcv (\%) & $\mathrm{Hb}(\mathrm{g} / \mathrm{dl})$ & $\operatorname{RBC}\left(\times 10^{9}\right)$ & WBC $\left(\times 10^{9}\right)$ & PLT $\left(\times 10^{9}\right)$ \\
\hline 1 & Distilled water alone & $47.0 \pm 1.0$ & $15.4 \pm 0.5$ & $10.8 \pm 0.5$ & $9.5 \pm 2.1$ & $716.5 \pm 14.5$ \\
\hline 2 & Stem extract $(250 \mathrm{mg} / \mathrm{kg} \mathrm{bw})$ & $43.7 \pm 0.9$ & $14.5 \pm 0.2$ & $8.5 \pm 0.0^{\mathrm{a}}$ & $8.3 \pm 1.3$ & $809.5 \pm 2.5$ \\
\hline 3 & Stem extract $(750 \mathrm{mg} / \mathrm{kg} \mathrm{bw})$ & $42.7 \pm 0.7$ & $14.5 \pm 0.5$ & $8.2 \pm 0.3^{\mathrm{a}}$ & $8.7 \pm 0.6$ & $759.0 \pm 11.5$ \\
\hline 4 & Stem extract (1500 mg/kg bw) & $44.0 \pm 0.0$ & $14.5 \pm 0.2$ & $7.6 \pm 0.5^{\mathrm{a}}$ & $6.5 \pm 1.0$ & $682.7 \pm 32.9$ \\
\hline 5 & Stem extract (2250 mg/kg bw) & $44.8 \pm 0.5$ & $14.5 \pm 0.2$ & $8.6 \pm 0.2^{\mathrm{a}}$ & $10.1 \pm 1.7$ & $748.0 \pm 14.2$ \\
\hline 6 & Stem extract (3000 mg/kg bw) & $44.8 \pm 1.0$ & $14.3 \pm 0.2$ & $8.4 \pm 0.2^{\mathrm{a}}$ & $9.6 \pm 1.4$ & $826.7 \pm 20.5$ \\
\hline
\end{tabular}

involved in the synthesis of choline and cholesterol. It has been reported to have hypoglycemic effect. ${ }^{31,32}$ It was also reported that magnesium may substitute for manganese as enzyme cofactor without compromising enzyme activity. ${ }^{31}$ Magnesium has been noted to affect glucose, calcium and iron homeostasis; stimulate vasodilatation and lower blood pressure. ${ }^{33,34}$ These elements may also contribute to antihypertensive and hypoglycemic tendencies of the extracts.

Iron has been associated with hemoglobin synthesis and erythrocyte production and plants are known to be good sources of non-heme iron. ${ }^{35}$ It has been noted that absorption of non-heme iron was influenced by iron status; dietary factors such as phytate, tannins and excess of some mineral elements such as calcium, phosphorus, manganese, zinc and copper. ${ }^{36}$ Thus the level of manganese in the plant extracts may have some influence in the iron homeostasis as indicated by the RBC count results.

The root extract caused no significant change in the hematological parameters except for the WBC. Reduction in the level of WBC has been attributed to immunosuppressant activity and may also result from reduced production and redistribution from peripheral blood into tissues or rapid destruction of WBC. ${ }^{37,38} \mathrm{~A}$ greater proportion of WBC is composed of lymphocytes and reduction in T-lymphocyte number, blastogenesis and mitogenesis have been reported for iron deficiency. ${ }^{39}$
Increase in circulating platelets (thrombocytosis) has been attributed to initial response to toxic effect and a decrease resulting from decreased haematopoiesis..$^{40,41}$

Except for $\mathrm{WBC}$ which was significantly $(\mathrm{P}<0.05)$ reduced: also indicating immunosuppressant activity, the pod extract had no affect on the peripheral blood. ${ }^{37}$ The expected increase in the level of RBC due to significant concentration of elemental iron may have been reversed due to the high level of manganese in the pod. Manganese has been suggested to compete with iron for binding site in the specific iron-binding $\beta_{1}$-globulin, transferrin, in the plasma. Also, the degree of saturation of transferrin affects iron deposition in the liver and its release to red blood cell precursors. ${ }^{42}$

The stem extract caused a significant $(\mathrm{P}<0.05)$ reduction in the $\mathrm{RBC}$ value for all the doses, compared to control. Iron is a principal component of $\mathrm{RBC}$ and was found to have $52-78 \%$ contribution to RDA (Table 2). The reduction in RBC may be related to the presence of some factors that influence absorption of non-heme (plant) iron. These include dietary factors such as glycosides-especially cyanogenic glycosides, phytate, tannins and manganese. ${ }^{36,43}$ But with the levels of PCV and $\mathrm{Hb}$ unaffected, the reduction in $\mathrm{RBC}$ may also arise from other sources including increased water intake, hemolysis or suppression of erythropoietin production. ${ }^{44,45}$ The reduction of WBC by extract is suggestive of the effect of some of the constituents on WBC circulation or formation. 
Thus the aqueous extract of root, pod and stem of Telfairia occidentalis are rich sources of potassium, magnesium, manganese and iron. The antihypertensive property ascribed to Telfairia occidentalis may be contributed by the potassium and magnesium content of the plant. The availability of the elemental iron may be dependent on other factors that influence iron metabolism, including antinutritional factors and competing elements. Their effects on WBC may be attributed to their antimicrobial or immunosuppressive effects.

\section{REFERENCES}

1. Chandy L and Gertz G. Poverty in numbers: the changing state of global poverty from 2005-2015. Washington DC: The Brookings Institution, 2011; 15.

2. Food and Agricultural Organisation. The State of Food Insecurity in the World 2012. Economic growth is necessary but not sufficient to accelerate reduction of hunger and malnutrition. 2012.

3. Gbile ZO. Ethnobotany, Taxonomy and Conservation of Medicinal plants. In: Sofowara A, ed. The State of Medicinal Plants in Nigeria. Ibadan: University of Ibadan Press, 1986.

4. Alada AR. The hematological effect of Telfairia occidentalis diet preparation. African Journal of Biomedical Research 2000; 3: $185-186$.

5. Ajayi Al, Ajayi TC, Omoaro EU and Halim NK. Erythropoietic value of pumpkin leaf extracts in rabbits- a preliminary study. Nigerian Journal of Physiological Sciences 2000; 16: 1-3.

6. Eseyin OA, Ebong P, Ekpo A, Igboasoiyi A and Oforah E. Hypoglycemic effect of the seed extract of Telfairia occidentalis in rats. Pakistan Journal of Biological Sciences 2007; 10: 498-501.

7. Eseyin OA, Ebong P, Eyong E, Awofisayo O and Agboke A. Effect of Telfairia occidentalis on oral glucose tolerance in rats. Afr J Pharm Pharmacol 2010; 4(6): 368-372.

8. Kayode AAA and Kayode OT. Some medicinal values of Telfairia occidentalis: A review. Am J Biochem Mol Biol 2010; 1: 30-38.

9. Ejike CECC and Ezeanyika LUS. A Telfairia occidentalis seedincorporated diet may be useful in inhibiting the induction of experimental andropause. Ann Med Health Sci Res 2012; 2(1): 41-45.

10. Ogbonnaya EA and Uadia PO. Short term effect of aqueous extracts of root, pod, and stem of Telfairia occidentalis on some biochemical parameters in rats. J Appl Sci Environ Manage 2014; 18(1): 123-128.

11. Ogbonnaya EA, Monago CC and Belonwu DC. Phytochemical Screening, Acute- and Organ-Toxicity Evaluwation of Telfairia occidentalis Root Aqueous Extract on Normal Wister Rats. Research Journal of Pharmacognosy and Phytochemistry 2010; 2(5): 340-343.

12. Ben Mussa SA, Elferjani HS, Haroun FA and Abdelnabi FF. Determination of available nitrate, phosphate and sulfate in soil samples. Int J PharmTech Res 2009; 1(3): 598-604.

13. National Research Council. Recommended dietary allowances. 1989.

14. Snieszko SF. Microhaematocrit as a tool in fisheries research. US fish and wildlife Service Special Scientific Report, 1960, 341:15.

15. Timm U, Lewis E, McGrath D, Kraitl J and Ewald H. LED based sensor system for non-invasive measurement of the hemoglobin concentration in human blood. IFMBE Proceedings 2009; 23: 825-828.

16. Alagoa KJ. Effect of Goldcrew and Corexit on selected blood parameter of the African cat-fish Clarias gariepinus following sublethal exposures. J Environ Chem Ecotoxicol 2010; 2(5): $67-72$.

17. Idris S. Compositional studies of Telfairia occidentalis leaves. Am J Chem 2011; 1(2): 56-59.

18. Su M, Stork C, Ravuri S, Lavoie T, Anguish D, Nelson LS and Hoffman RS. Sustained-release potassium chloride overdose. J Toxicol Clin Toxicol 2001; 39:641-648.

19. He FJ and MacGregor GA. Beneficial effects of potassium on human health. Physiol Plantarum 2008; 133:725-735.

20. Ando K, Matsui H, Fujita M and Fujita T. Protective effect of dietary potassium against cardiovascular damage in saltsensitive hypertension: possible role of its antioxidant action. Curr Vasc Pharmacol 2010; 8(1): 59-63.

21. He FJ, Marciniak M, Carney C, Markandu ND, Anand V, Fraser WD, et al. Effects of potassium chloride and potassium bicarbonate on endothelial function, cardiovascular risk factors, and bone turnover in mild hypertensives. Hypertension 2010; 55:681-688.

22. Ekpenyong CE, Akpan EE and Udoh NS. Phytochemistry and toxicity studies of Telfairia occidentalis aqueous leaves extract on liver biochemical indices in wistar rats. Am J Med Med Sci 2012; 2(5): 103-110.

23. Swaminathan R. Magnesium metabolism and its disorders. Clin Biochem Rev 2003; 24(2): 47-66.

24. Ajayi OB. Micronutrient changes in some tissues of copper deficient rats. Pak J Nutr 2005; 4(2): 123-125.

25. Korc M. Manganese homeostasis in humans and its role in disease states. In: Korc, M, ed. Essential and toxic trace elements in human health and disease. New York: Alan R. Liss, 1988, pp 253-273.

26. Wedler FC. Biochemical and nutritional role of manganese: an overview. In: Kllimis-Tavantzis, DJ, ed. Manganese in health and disease. BocaRaton: CRC press, 1994.

27. Ashner M, Vrana KE and Zheng W. Manganese uptake and distribution in the central nervous system (CNS). Neurotoxicology 1999; 20:173-180.

28. Crossgrove $\mathrm{J}$ and Zheng $\mathrm{W}$. Manganese toxicity upon overexposure. NMR Biomed 2004; 17:544-553.

29. Sziraki I, Rauhala P and Chiueh CC. Novel protective effect of manganese against ferrous citrate-induced lipid peroxidation and nigrostriatal neurodegeneration in vivo. Brain Res 1995; 698: 285-287.

30. Chen MT, Sheu JY and Lin TH. Protective effects of manganese against lipid peroxidation. J Toxicol Environ Health 2000 A61: 569-577.

31. McDowell LR. Minerals in Animal and Human Nutrition. San Diego, CA: Academic Press Inc, 1992.

32. Al-Awadi FM, Amin JT, Srikuma TS and Al-Rustom M. Possible role of trace element in the hypoglycemic effects of plant extract in diabetics rats. The Journal of Trace Element in Exptl Medicine 2004; 17: 31-44.

33. Nadler JL, Buchanan T, Natarajan R, Antonipillai I, Bergman R and Rude R. Magnesium deficiency produces insulin resistance and increased thromboxane synthesis. Hypertension 1993; 21: 1024-1029.

34. Nadler JL and Rude RK. Disorders of magnesium metabolism. Endocrinol Metab Clin North Am 1995; 24:623-641.

35. Waldovogel-Abramowski S, Waeber G, Gassner C, Buser A, Frey BM, Favrat B, et al. Physiology of iron metabolism. Transfus Med Hemother 2014; 41:000-000. 
36. Hallberg $L$ and Rossander-Hulthen $L$. Factors influencing the bioavailability of iron in man. In: Schlemmer U, ed. Bioavailability '93-Nutritional, Chemical and Food Processing Implications of Nutrient Availability. Federal Republic of Germany: Ettlingen,1993, pp 23-32.

37. Oyewole OI, Malomo SO and Arise RO. Haematological evaluation in rats following administration of some antisickling agents. Int J Biol Chem Sci 2009; 3(2): 410-414.

38. Debaun MR. Hydroxylurea as secondary prevention for stroke in children with sickle cell anaemia. J Pediatri 2005; 147: 560-561.

39. Kuvibidila SR, Kitchens D and Baliga BS. In vivo and in vitro iron deficiency reduces protein kinase $\mathrm{C}$ activity and translocation in murine splenic and purified T cells. J Cell Biochem 1999; 74:468-478.

40. Mbajiorgu E, Aire T, Volk $\mathrm{W}$, Albert $\mathrm{M}$ and Debusho $\mathrm{L}$. Haematological Profile of Male Rats Treated with Ethanol and/ or Chloroquine and fed Normal or Low Protein Diet. The Internet Journal of Hematology 2006; 3(1): 1-11.

41. Harold $S$ and Ballard MD. The hematological complications of alcoholism. Alcohol Health Res World 1997; 21: 42-52.

42. Ganz T. Hepcidine and iron regulation, 10 years later. Blood 2011; 117(17): 4425-4433.

43. Adedapo AA, Mogbojuri OM and Emikpe BO. Safety evaluations of the aqueous extract of the leaves of Moringa oleifera in rats. J Med Plants Res 2009; 3(8): 586-591.

44. Matulka RA, Lyon MR, Wood S, Marone PA, Merkel DJ and Burdock GA. The safety of PolyGlycopleX (PGX) as shown in a 90-day rodent feeding study. Nutr J 2009; 8:1.

45. Ikpi DE and Nku CO. Effect of ethanolic extract of Dennettia tripetala fruit on hematological parameters in rats. Niger $\mathrm{J}$ Physiol Sci 2008; 23(1-2): 13-17.

EAO - Initiated, designed and carried out the research, and compiled manuscript; POU - Supervised research design and experimentation, revised manuscript. 